\title{
Television use and nutrient intakes in young children from the first year of the National Diet and Nutrition Survey rolling programme
}

\author{
N. Ziauddeen ${ }^{1}$, G. K. Pot $^{1}$, C. J. Prynne ${ }^{1}$, B. Bates ${ }^{2}$, H. Henderson ${ }^{2}$, S. Pigott ${ }^{2}$, C. Deverill ${ }^{2}$ \\ and A. M. Stephen ${ }^{1}$ \\ ${ }^{1}$ MRC Human Nutrition Research, Elsie Widdowson Laboratory, 120 Fulbourn Road, Cambridge CB1 9NL, UK and \\ ${ }^{2}$ National Centre for Social Research, 35 Northampton Square, London EC1V OAX, UK
}

Television use has been associated with unhealthy dietary behaviour leading to overweight and obesity and may represent a modifiable lifestyle factor ${ }^{(1,2)}$. We investigated the association of television use and nutritional quality, assessed through intake of indicator nutrients: total energy, macronutrients as percentage of energy, vitamin $\mathrm{C}, \mathrm{Fe}$ and $\mathrm{Ca}$. Data for children aged 1.5-6 years of the first year of the National Diet and Nutrition Survey rolling programme ${ }^{(3)}$ were used ( $n$ 222), collected between February 2008 and March 2009. Dietary data were collected in the form of $4 \mathrm{~d}$ estimated diaries, each day recorded in seven timeslots. For each eating occasion, participants were also asked to indicate whether the television was on or off. Nutrient intakes were calculated using the dietary assessment system (Diet in Nutrients Out) developed at MRC Human Nutrition Research incorporating the NDNS Nutrient Databank.

Less food were consumed with the television on (42\%) as compared with having the television off (58\%). For children aged 1.5-3 years ( $n$ 121) $47 \%$ of eating occasions were reported as having the television on, compared with $35 \%$ of occasions for children aged 4-6 years ( $n$ 101). Results showed that for both 1.5-3 years and 4-6 years old children who had the television on, time slots tended to have higher intakes of carbohydrate and lower intakes of fat compared with those with the television off; although statistical significance was achieved for both nutrients only in the early morning $(6-8.59 \mathrm{~h})$ and for carbohydrate only in the early afternoon (12-13:59h). For timeslots with the television on, intakes were significantly lower for energy, protein, fat, $\mathrm{Ca}$ and $\mathrm{Fe}$ in the early afternoon (12-13:59h) when compared with the television off. Variations were observed during the day at different timeslots; however, results indicated that timeslots with the television on showed higher intakes of energy, $\mathrm{Ca}$ and Fe in the mid-morning (9-11.59 h), late afternoon (14-16.59 h), late evening $(8-9.59 \mathrm{~h})$ and late night $(22.00 \mathrm{~h}-5.59 \mathrm{~h})$; and vitamin $\mathrm{C}$ in the late afternoon $(14.00-16.59 \mathrm{~h})$ and late night $(22.00 \mathrm{~h}-5.59 \mathrm{~h})$.

When further subdivided by age group, a similar trend for carbohydrate and fat intake was observed in children aged 1.5-3 years as for all ages; although statistical significance was now achieved in the late evening $(20.00-21.59 \mathrm{~h})$ instead of the early afternoon (12-13.59 h); for children aged 4-6 years no differences in fat intake by television was seen. For children aged 1.5-3 years, a lower protein intake was seen for all timeslots through the day when the television was on but no association was observed for children aged 4-6 years.

Despite variations observed in nutrient intake with television use over the day and between age groups, a trend for lower nutritional quality was observed with having the television on in children under the age of six, especially in children under the age of three. Thus, interventions designed to reduce television viewing during eating could positively affect children's nutrient intakes.

1. Robinson TN (1999) JAMA 282(16), 1561-1567.

2. Matheson DM, Killen JD, Wang Y et al. (2004) Am J Clin Nutr 79, 1088-1094.

3. Bates B, Lennox A \& Swan G. NDNS Headline results from Year 1 of the Rolling Programme. Available at www.food.gov.uk/multimedia/pdfs/ publication/ndnsreport0809.pdf (accessed 18 January 2011). 